\title{
PERANCANGAN SISTEM INFORMSI E-JURNAL PADA PERGURUAN TINGGI BERBASIS WEB
}

\author{
Faridi $^{1}$ \\ Peni Aripianti ${ }^{2}$ \\ Retno Widuri $^{3}$
}

\begin{abstract}
Dosen STMIK Raharja Tangerang ${ }^{1}$, Mahasiswa STMIK Raharja Tangerang ${ }^{2,3}$ Jl.Jendral Sudirman No.40 Modernland, Tangerang ${ }^{1,2,3}$ e-mail:faridi@raharja.info ${ }^{1}$, peni.aripianti@raharja.info ${ }^{2}$,retno@raharja.info ${ }^{3}$
\end{abstract}

\begin{abstract}
ABSTRAK
Teknologi merupakan sesuatu yang tidak bisa lepas di era modern ini. Dengan munculnya teknologi mahasiswa dan dosen di mudahkan dalam mendukung proses belajar dan mengajar. Kewajiban menghasilkan sebuah paper jurnal ilmiah merupakan ketentuan yang di ciptakan demi meningkatkan mutu dan kualitas pendidikan di Indonesia. Perguruan Tinggi Rahaja merupakan salah satu lembaga pendidikan yang bergerak di bidang Ilmu Komputer selalu mengedepankan inovatif serta kreatif dalam memecahkan masalah-masalah. Aspek-aspek yang mendukung aktivitas di Akademik salah satunya yaitu dalam pembuatan karya tulis ilmiah oleh mahasiswa dan dosen yang akan dijadikan sebagai dokumentasi ilmiah. Oleh karena itu di butuhkannya suatu sistem untuk mendukung proses penciptaan dan publikasi jurnal. Sehingga di ciptakan lah suatu sistem "E-Jurnal" untuk mempermudah dalam mencari kumpulan-kumpulan jurnal yang juga mempermudah dalam penulisan jurnal.
\end{abstract}

Kata Kunci : Pendidikan, kampus, e-jurnal

\begin{abstract}
Technology is something that cannot be separated in this modern era. With the advent of technology scholars and lecturers on the make in support of the process oflearning and teaching. Liabilities resulted in a scientific journal paper is a provision that is created in order improve the quality of education in Indonesia. Perguruan Tinggi Raharja is one of the educational institutions in the field of computer science always focuses on innovative and creative in solving a problems. Aspects that support the Academic activity at one of them, namely in making scientific papers by scholars and lecturers that will serve as the scientific documentation. Therefore it needs a system to support the creation and publication of the journal. So it was created a system of "E-Jurnal" for simplify the search for clusters journal has also simplify the journal writing.
\end{abstract}

Key words: Education, scholar, E-Jurnal 


\section{PENDAHULUAN}

Diera globalisasi, teknologi dalam dunia internasional perkembangan teknologi semakin pesat. Membuat setiap orang berlomba-lomba menciptakan suatu aplikasi yang canggih dengan memanfaatkan teknologi yang ada, aplikasi yang membantu manusia dalam melakukan aktivitasnya sehari-hari yang mudah, efektif dan efisien. E-Jurnal merupakan sebuah aplikasi berbasis web yang digunakan untuk pengumpulan dan pempublikasian jurnal yang sangat membantu khususnya bagi mahasiswa. E-Jurnal merupakan salah satu bukti bahwa teknologi saat ini sangat berkembang dengan pesat.

Perguruan Tinggi Raharja merupakan sebuah instansi pendidikan dalam bidang komputer, dimana semua jurusan yang ada pada Perguruan Tinggi Raharaja mempelajari dan mendalami ilmu komputer, sehingga banyak terciptanya aplikasi-aplikasi baru yang sangat membantu dalam proses pembelajaran.

Banyaknya aplikasi yang dibuat, ternyata masih belum cukup untuk membantu proses pembelajaran. Maka dari itu, diperlukan aplikasi-aplikasi tambahan untuk membantu mahasiswa maupun staff dalam melakukan aktivitas sehari-hari, terutama bagi mahasiswa yang akan melakukan pembuatan paper jurnal ilmiah yang merupakan sebuah syarat kelulusan. Mereka memerlukan media yang lebih praktis dalam pengumpulan maupun publikasi jurnal ilmiah tersebut. bukan hanya di perguruan tinggi raharja, di Universitas lain pun jurnal merupakan salah satu syarat kelulusan sesuai dengan keputusan pemerintah pada tahun 2012 menyatakan bahwa sebagai salah satu syarat kelulusan mahasiswa adalah wajib menghasilkan sebuah karya ilmiah dalam bentuk paper jurnal. Pada Perguruan Tinggi ataupun Universitas lain semua mahasiswa membutuhkan sebuah aplikasi sebagai media yang digunakan untuk menampung jurnal yang telah dipublikasikan. Oleh karena itu, dengan adanya aplikasi E-Jurnal sebagai suatu aplikasi berbasis web pendukung dalam publikasi jurnal ilmiah yang dapat diterapkan di Perguruan Tinggi dan Universitas.

\section{LANDASAN TEORI}

\section{A. Website}

Website merupakan media penyampaian informasi yang populer saat ini. Website menyajikan informasi menggunakan HTML sehingga dapat menampilkan informasi dengan berbagai format data seperti text, image bahkan video dan dapat diakses menggunakan berbagai aplikasi client. Selain dikenal sederhana dan mudah, adanya teknologi server side programming pada web memungkinkan penyajian yang didapat oleh pemakai komputer yang terhubung ke internet. Web pada awalnya informasi yang lebih menarik dan dinamis dengan pengelolaan yang terorganisasi. (Mambrasar, 2008:1)

World Wide Web (WWW) dikenal dengan web yang merupakan salah satu layanan adalah ruang informasi dalam internet, dengan menggunakan teknologi hypertext, pemakai dituntun untuk menemukan informasi dengan menggukan link yang disediakan dalam dokumen web yang ditampilkan dalam browser web. Kini internet identik dengan web, Karena kepopuleran web sebagai standar interface pada layanan-layanan yang ada di internet, dari awalnya sebagai penyedia informasi, kini digunakan juga untuk komunikasi dari email sampai dengan chatting, dan juga dalam melakukan transaksi bisnis (commerce). Web memudahkan pengguna komputer untuk berinteraksi dengan pelaku internet lainnya dan menelusuri informasi di intenet.

Selain itu, web telah digunakan oleh perusahaan-perusahaan sebagai sebagian dari strategi teknolgi informasinya, karena adanya beberapa alasan :

a. Akses informasi mudah

b. Setup server lebih mudah 
c. Informasi mudah didistribusikan, dan

Informasi dapat disajikan oleh browser web pada sistem operasi mana saja karena adanya standar dokumen berbagai tipe data dapat disajikan (Sidiq, 2010:1-2)

\section{B. Hypertext Preprocessor (PHP)}

PHP merupakan kependekan dari kata Hypertext Preprocessor. PHP tergolong sebagai perangkat lunak open source yang diatur dalam aturan General Purpose Licence (GPL).

Pemrograman PHP sangat cocok dikembangkan dalam lingkungan web, karena PHP bisa dilekatkan pada script html atau sebaliknya. PHP dkhususkan untuk pengembangan web dinamis. PHP tergolong sebagai Bahasa pemrograman yang berbasis server ( server side scripting). Ini berarti semua sript PHP diletakan di server dan diterjemahkan oleh web server terlebih dahulu, kemudian hasil terjemahan itu dikirim ke browser client. (Suprianto, 2008:17)

PHP bersifat free (bebas dipakai). Kita tidak perlu membayar apapun untuk menggukan perangkat lunak ini. Kita dapat mengunduh PHP melalui situs resminya yaitu www.PHP.net. Untuk versi windows, kita dapat memperoleh kode binernya. Dan untuk versi linux, kita mendapatkan kode sumbernya secara lengkap. Kelahiran PHP bermula saat Rasmus Lerdorf membuat sejumlah script PERL yang dapat mengamati siapa saja yang melihat-lihat daftar riwayat hidupnya, yakni pada tahun 1994. Skrip-skrip ini selanjutnya dikemas menjadi tool yang disebut "Personal Home Page". Kumpulan tool inilah yang nantinya menjadi cikal-bakal PHP. Pada tahun1995, Rasmus menciptakan PHP/FI versi 2. Pada versi inilah pemrograman dapat menempelkan kode terstruktur didalam tag HTML. Yang menarik, kode PHP juga bisa berkomunikasi dengan database dan melakukan perhitungan-perhitungan yang kompleks sambil jalan.

Pada awalnya, PHP didesain untuk diintegrasikan dengan webserver Apache. Namun belakangan ini, PHP juga dapat bekerja dengan webserver seperti PWS(Personal Web Server), IIS (Internet Information Server) dan Xitami. Yang membedakan PHP dengan bahasa pemrograman lainnya adalah adanya tag penentu. Yaitu diawali dengan " $<$ ?" atau "<?PHP" dan diakhiri dengan "? >". jadi kita bebas menempatkan skrip PHP dimanapun dalam dokumen html yang telah kita buat. (Suprianto, 2008:18-19)

\section{Jurnal}

Jurnal merupakan salah satu koleksi di dalam perpustakan yang di butuhkan oleh pengguna untuk menemukan informasi tentang penemuan ilmiah terkini (current). Seperti yang dijelaskan diatas jurnal merupakankoleksi perpustakaan dalam kategori koleksi serial. Menurut Siregar (2012:11) mengemukakan bahwa "koleksi serial adalah semua bahan perpustakaan yang diterbitkan secara berlanjut bukan terbitan tunggal (monograph)seperti buku. Koleksi ini terdiri dari jurnal, majalah, surat kabar dan terbitan berkalalainnya".

Adapun pengertian dari jurnal menurut pendapat Highbeam (2012:11) " journal is the collection and periodic publication or transmission of news and the result of research through media, artinya bahwa jurnal merupakan suatu koleksi dan terbitan berkala atau transmisi mengenai berita dan hasil-hasil penelitian mengenai media.

\section{Jurnal elekronik (e-Jurnal)}

Tresnawan (201:15) artikel jurnal elektronik menyebutkan bahwa "jurnal elektornik adalah terbitan serial seperti bentuk tercetak tetapi bentuk elektronik, biasanya terdiri dari tiga format, yaitu teks, teks dan grafik, serta full image (dalam bentuk pdf)".

Menurut Rowleydalam (2012:15) menyatakan bahwa "electronic journals take two different forms: (1) journal that are otherwise published in print form, available in digital form, (2) electronic only journals, which do not necessarily need a published"

\section{E. Jurnal elektronik berbasis web}


Munthasir (2012:15) menyataka pada dasarnya "jurnal online merupakan suatu jurnal yang dikonversikan kedalam bentuk digital dan ditempakan pada database yang hanya bisa diakses melalui internet"

\section{F. Web Server}

Web server adalah suatu program komputer yang mempunyai tanggung jawab atau tugas menerima permintaan HTTP dari klien, yang dikenal dengan nama web browser, dan melayani mereka dengan menyediakan respon HTTP berupa konten data, biasanya berupa halaman web yang terdiri dari dokumen HTML, dan objek terkait seperti gambar dan lainlain.

\section{G. MySQL}

MySQL adalah sebuah server database opensource yang populer keberadaannya. MySQL umumnya digunakan bersamaan dengan script PHP untuk membuat aplikasi server yang dinamis dan powerful

\section{H. Database}

Sebuah database adalah sebuah struktur yang umumnya dikategorikan dalam 2 hal: Sebuah database flat dan sebuah database relasional. Database relasional lebih disukai karena lebih masuk akal dibandingkan database flat. MySQL adalah sebuah database relasional.

I. SQL

SQL (dibaca "ess-que-el") merupakan kependekan dari Structured Query Language. SQL digunakan untuk berkomunikasi dengan dengan sebuah database. Sesuai dengan ANSI, SQL merupakan bahasa standar untuk sistem menajemen database relasional.

\section{PERMASALAHAN}

Melihat pada sistem pengumpulan E-Jurnal yang telah disetujui untuk diterbitkan di Perguruan Tinggi . Pada sistem pengumpulan E-Jurnal semua Jurnal akan di cetak kedalam beberapa buku. Aspek-aspek pendukung dalam suatu aktivitas di Akademik adalah unsur karya penelitian secara ilmiah oleh (mahasiswa dan dosen) dan diolah menjadi suatu karya tulis ilmiah (Jurnal Ilmiah) yang akan dijadikan sebagai dokumentasi penelitian. beberapa kekurangan, menuntut perguruan tinggi dan universitas lain untuk membuat sebuah inovasi baru yang diciptakan oleh perguruan tinggi dan universitas tersebut dalam pembuatan sebuah aplikasi yang sebelumnya belum pernah ada.

Karena mahasiswa Perguruan Tinggi membutuhkan suatu aplikasi yang dapat mempermudah dalam mencari kumpulan-kumpulan jurnal ilmiah dan mempermudah dalam publikasi jurnal ilmiah tersebut Karena sistem pengumpulan E-Jurnal membutuhkan suatu sistem yang dapat mempermudah dalam mencari kumpulan-kumpulan Jurnal sesuai kategori tahun terbitnya dan mempermudah dalam penulisan Jurnal. Serta sistem yang dibuat sebelumnya masih belum efektif dan efisien, dengan sistem percetakan kedalam bentuk buku akan menghabiskan dana yang cukup besar.

Tidak hanya biaya namun dalam percetakan berbentuk buku maka akan menghabiskan kertas yang cukup banyak yang dapat meningkatkan dampak pemanasan global. Dari sistem yang telah diterapkan sebelumnya masih banyak kekurangan-kekurangan yang dapat dan harus diperbaiki guna menunjang sistem yang lebih efektif dan efisien.

Dari penjelasan diatas dapat dirumuskan beberapa permaslahan yaitu sebagai berikut

1. Bagaimana proses pembuatan aplikasi E-Jurnal ?

2. Apakah sistem E-Jurnal dapat membantu perubahan sistem publikasi paper jurnal ilmiah pada perguruan tinggi ? 


\section{LITERATURE REVIEW}

1. Jaringan Internasional untuk Ketersediaan Publikasi Ilmiah (INASP) untuk mengembangkan portal penelitian ilmiah di Afrika, Jaringan Internasional untuk Ketersediaan Publikasi Ilmiah (INASP) adalah sebuah organisasi amal yang didirikan tahun 1992 oleh Dewan Internasional untuk Science (ICSU), dan didaftarkan sebagai lembaga amal Inggris pada tahun 2004. Melalui kemitraan strategis, partisipasi stakeholder dan komitmen untuk tanggung jawab sosial, INASP. Program-program ini saat ini berfokus pada penguatan komunikasi penelitian, dengan penekanan khusus pada kebutuhan negara berkembang dan negara berkembang [3].

2. Nepal, (NepJOL) dimulai pada bulan Juni 2006 dan resmi diluncurkan pada bulan September 2007. Ini adalah proyek yang didukung oleh Jaringan Internasional untuk Ketersediaan Publikasi Ilmiah (INASP). Ini bertujuan untuk mempromosikan kesadaran dan penggunaan Nepal-jurnal diterbitkan dalam semua disiplin dengan menyediakan akses ke isi tabel (TOCs), abstrak dan teks lengkap di Internet [4].

3. Proceedings ITB, jurnal ilmiah resmi ITB, telah diterbitkan sejak 1961. Jurnal ini merupakan sarana publikasi hasil penelitian dalam bidang IPTEKS yang dilakukan oleh civitas akademika ITB dan oleh kontributor dari luar ITB. Sejak edisi 2007 [ Volume 39 ], Proceedings ITB mengubah namanya menjadi ITB Journal dan mengeluarkan 4 seri .

4. ITB Journal of Science terbit dua kali setahun pada bulan Maret dan September. Naskah ditulis dalam bahasa Inggris. ISSN:1978-3043 [9].

5. ITB Journal of Engineering Science terbit dua kali setahun pada bulan Mei dan November. Naskah ditulis dalam bahasa Inggris. ISSN: 1978-3051 [10].

6. ITB Journal of Information and Communication Technology terbit dua kali setahun pada bulan Mei dan November. Naskah ditulis dalam bahasa Inggris. ISSN: 1978-3086 [11].

7. ITB Journal of Visual Art and Design terbit tiga kali setahun pada bulan Maret, Agustus dan Desember. Naskah ditulis dalam bahasa Indonesia. ISSN: 1978- 3078. Mulai Volume 35 No. 1, 2003, abstrak dan artikel ITB Journal yang telah diterbitkan dapat dibaca secara online dengan mengunjungi situs web [12] .

8. Penelitian yang dilakukan oleh Trent Batson dari The Association for Authentic, Experiential and Evidence-Based Learning (AAEEBL) yang berjudul "12 Important Trends in the ePortfolio Industry for Education and for Learning" tahun 2012. Penelitian ini membahas tentang sebuah portofolio elektronik milik pelajar: sebuah aplikasi berbasis web yang dapat meng-upload dan menyimpan setiap jenis file untuk melayani sebagai bukti dalam presentasi dari e-portfolio, seperti untuk kelulusan atau untuk mendapatkan pekerjaan. Dengan demikian catatan elektronik dari prestasi yang dapat terus disortir dan dimusnahkan dari waktu ke waktu. Ini adalah repositori aktif dengan alat manajemen banyak yang dapat menghasilkan presentasi web untuk tujuan tertentu, itu adalah resume pembuat dengan bukti terkait. E-portfolios memungkinkan bergerak dari pendidikan (pendidik sebagai agen aktif) untuk belajar. "Dalam waktu pengetahuan stabil, mengajar, dalam waktu pengetahuan cepat berubah, belajar. Ini adalah waktu untuk belajar: Mulai semua pemikiran berdasarkan pertimbangan tentang belajar. Pendidikan menganggap satu set bidang pengetahuan, membatasi penemuan pelajar itu, bidang di mana semua pengetahuan telah ditemukan dan dianalisa, melainkan menganggap siswa akan ditindaklanjuti oleh pendidik bukan mahasiswa / pelajar bertindak atas pengetahuan,. itu menganggap satu jalur untuk semua peserta didik fokus pada belajar, e-portfolios memungkinkan pendidik untuk melakukan, membuka pengalaman belajar. [6]. 
9. Penelitian yang di lakukan oleh Untung Rahardja, Dewi Immaniar Desrianti, dan Siti Mawadah pada tahun 2011 di Perguruan Tinggi yang berjudul "Ibooks Standardisation And Good Practice for Effective Education Methods in Support of Ilearning “ menjelaskan bahwa iBooks adalah salah satu aplikasi yang mendukung iLearning yang sangat membantu kita untuk mengorganisir berbagai macam kumpulan buku-buku yang kita upload, baik berupa pdf atau dokumen lainnya. Dengan adanya iBooks, kita bisa mendapatkan kemudahan dalam membaca karena di dalamnya kita dapat mengkategorikan file yang berupa pdf atau dokumen lainnya. User dapat dengan mudah mengunduh buku yang diinginkan. Spesifikasi yang berada di dalam iBooks sangat mempengaruhi berjalannya suatu kegiatan belajar mengajar berbasis iLearning[11].

10. Penelitian yang dilakukan oleh Untung Rahardja, Augury El rayeb, dan Heriyanto dari Perguruan Tinggi Raharja, Indonesia [23], pada tahun 2010 yang berjudul "Pengolahan Jurnal Elektronik Dengan Online Jurnal System". Pada penelitian ini menjelaskan mengenai sistem penampungan hasil-hasil riset. Namun sistem ini masih bersifat manual, belum menggunakan database terstruktur dan perlu melibatkan personil terkait untuk mengendalikan alur sistem serta penggunaan banyak kertas untuk berkas data sebagai pendukungnya. Sehingga sistem tersebut tidak berjalan secara maksimal. Maka perlu adanya sebuah online jurnal system yang dapat dijalankan secara langsung (self service), dapat pula berkomunikasi via-email (intranet), penggunaan sedikit kertas (paper less), serta sudah menggunakan database yang baik karena dapat memberikan dampak yang cukup signifikan terhadap kelangsungan 4 (empat) pilar IT e-learning hasil dari penelitian di lingkungan Perguruan Tinggi Raharja.

11. Penelitian yang dilakukan oleh Iwan Budiawan pada tahun 2008 yang berjudul "Perancangan Sistem Informasi Hasil Penelitian Dosen Berbasis Web Pada Perguruan Tinggi Raharja”. Penelitian ini menjelaskan bahwa sistemnya masih menggunakan web base yang bersifat statis, sehingga masih mengalami kesenjangan dalam mencari hasil penelitian, hasil penelitian belum terdokumentasi dengan baik dan lamanya proses pengajuan penelitian. Maka dibuatlah suatu sistem web base yang bersifat dinamis yang memudahkan, menyesuaikan sesuai dengan hasil penelitian dosen. Sehingga dapat mempermudah dosen dalam mengirim penelitian, mengetahui informasi hasil penelitian yang dosen kirim tanpa membutuhkan waktu yang cukup lama, mempermudah reviewer dalam me-review dan mengetahui jumlah penelitian yang masuk, disetujui, maupun tidak disetujui, dan mempermudah user/pengunjung dalam mencari suatu informasi yang dibutuhkan dengan cepat[7].

\section{PEMBAHASAN}

\section{Diagram Use Case}

Rancangan dan Analisa terhadap proses utama dan pendukung untuk masalah tertentu adalah sebuah hal yang sangat penting dalam pembangunan sebuah perangkat lunak. Bahkan analisa kebutuhan dan data adalah langkah awal dalam pembangunan sebuah perangkat lunak. Dalam penelitian ini metode perancangan dibuat dengan menggunakan UML khususnya activity diagram dimana setiap tugas menunjukkan sebagai sebuah activity dari masalah tertentu. Serta untuk mengurangi komponen diagram dan menyembunyikan beberapa detail sub system seperti database dan perbaikan proses transaksi. Adapun activity diagram yang diusulkan adalah sebagai berikut: 


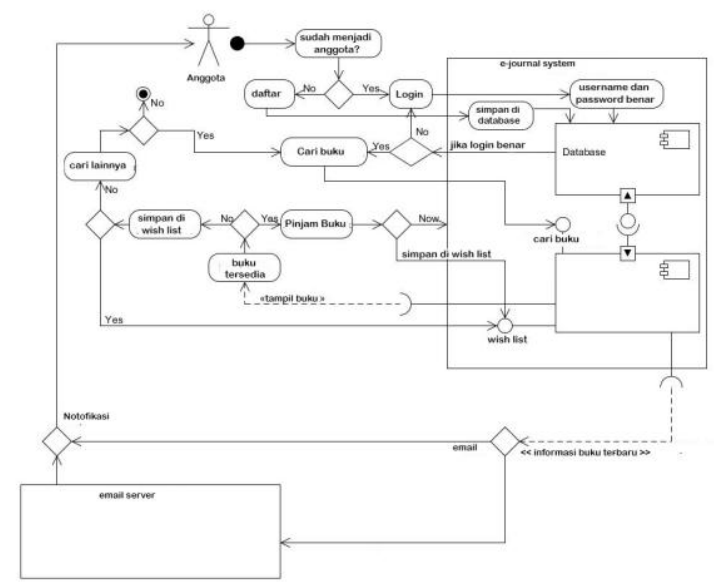

Gambar 1. Use case diagram

Untuk masuk ke system ini setiap anggota atau end user harus login terlebih dahulu. System akan memeriksa apakah akun yang dimasukkan sudah terdaftar di database, jika sudah terdaftar maka akan masuk kehalaman utama e-jurnal.

Setelah masuk kehalaman utama, kemudian melakukan pencarian di fasilitas search. Setelah jurnal ditemukan anggota membuka link pada judul jurnal, kemudian muncul detail jurnal yang dicari. Untuk memudahkan pencarian jurnal bagi setiap anggota dan jika suatu waktu anggota ingin melihat jurnal yang pernah di buka, anggota dapat menambahkannya pada daftar keinginan.

\section{Desain Database}

beberapa kampus sudah memiliki system repository untuk menampung penelitian yang pernah dilakukan namun masih menggunakan cms yang memiliki keterbatasan dari segi kustomisasi. Pembangunan lingkungan database baru untuk mendukung system e-journal pun mutlak diperlukan. Data yang berasal dari system yang sudah berjalan dapat dijadikan sebagai acuan untuk membuat database baru yang sesuai. Dengan penambahan beberapa fitur yang memudahkan pengguna dalam mendapatkan jurnal sesuai dengan kategori yang dicari.

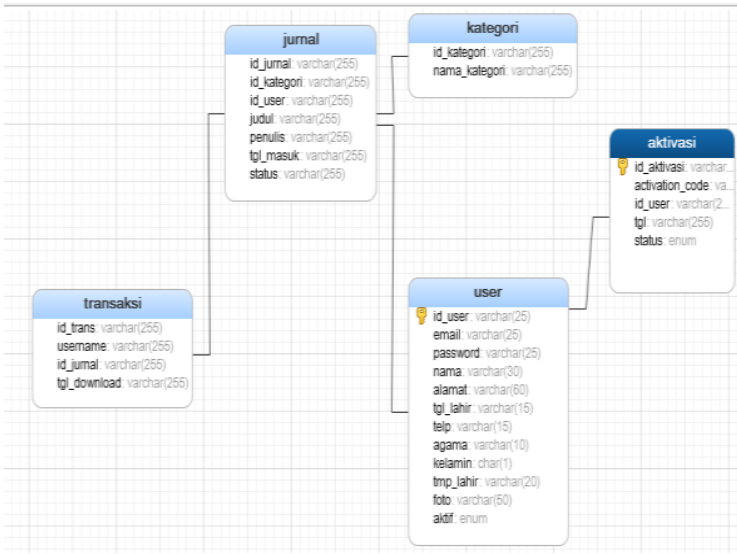

Gambar 2. Disain Database e-jurnal

\section{Rancangan Antar Muka}

\section{Login Pengguna}

Untuk masuk kedalam aplikasi e-jurnal, setiap pengguna harus lebih dahulu login dengan username dan password yang sudah diperoleh dari halaman registrasi. Karena aplikasi ini 
digunakan untuk lingkungan internal kampus maka pengguna dapat mendaftar dengan email yang sesuai dengan yang ditentukan oleh pihak kampus.

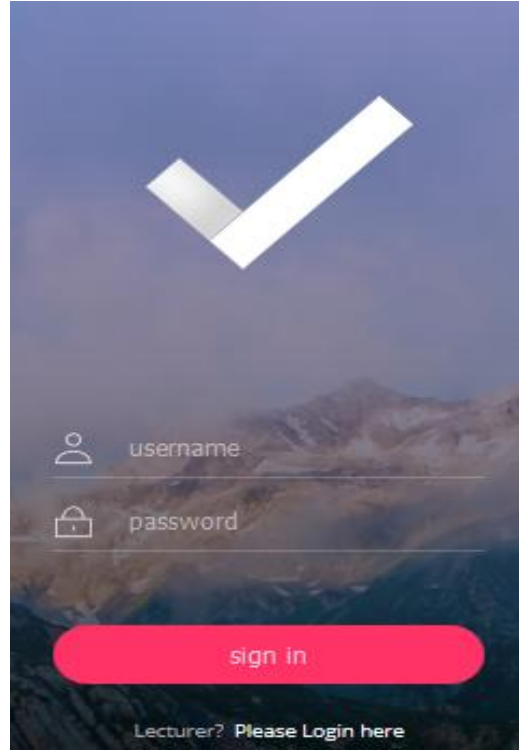

\section{Gambar 3. Form Login}

\section{Daftar Member}

Bagi mahasiswa atau dosen yang belum memiliki akun daftar mendaftar pada menu pendaftaran dengan mengisi field yang diberikan

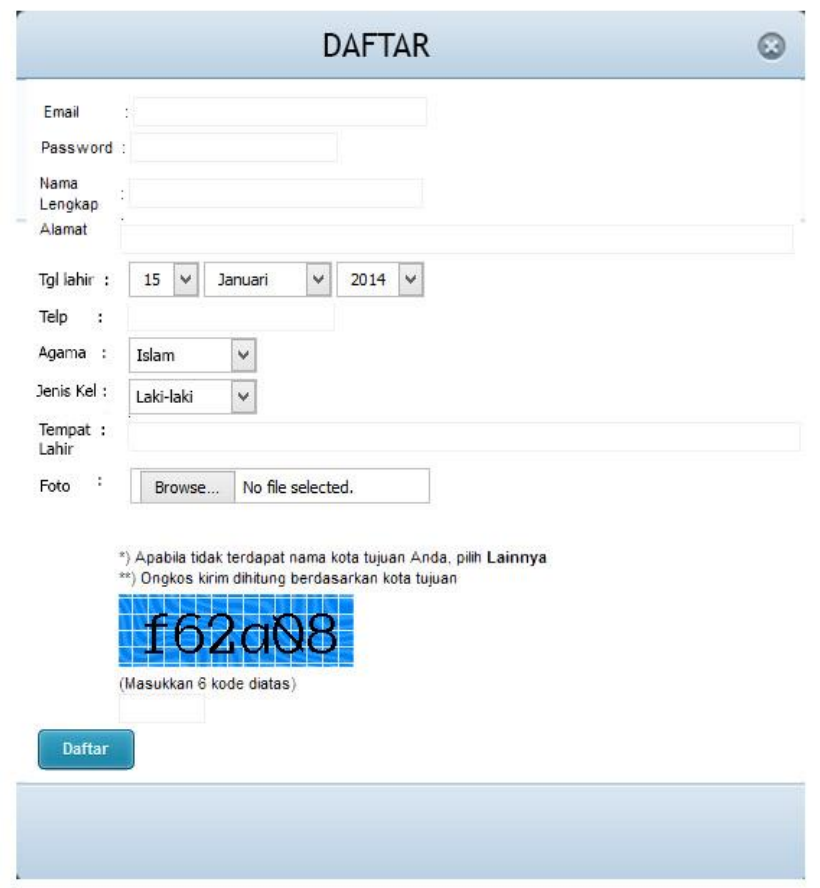

Gambar 4. Form pendaftaran member baru 


\section{Halaman Utama pengunjung}

Halaman utama pengunjung berisi judul penelitian yang pernah dilakukan. Disediakan fasilitas pencarian untuk pengunjung mencari artikal atau jurnal berdasarkan judul

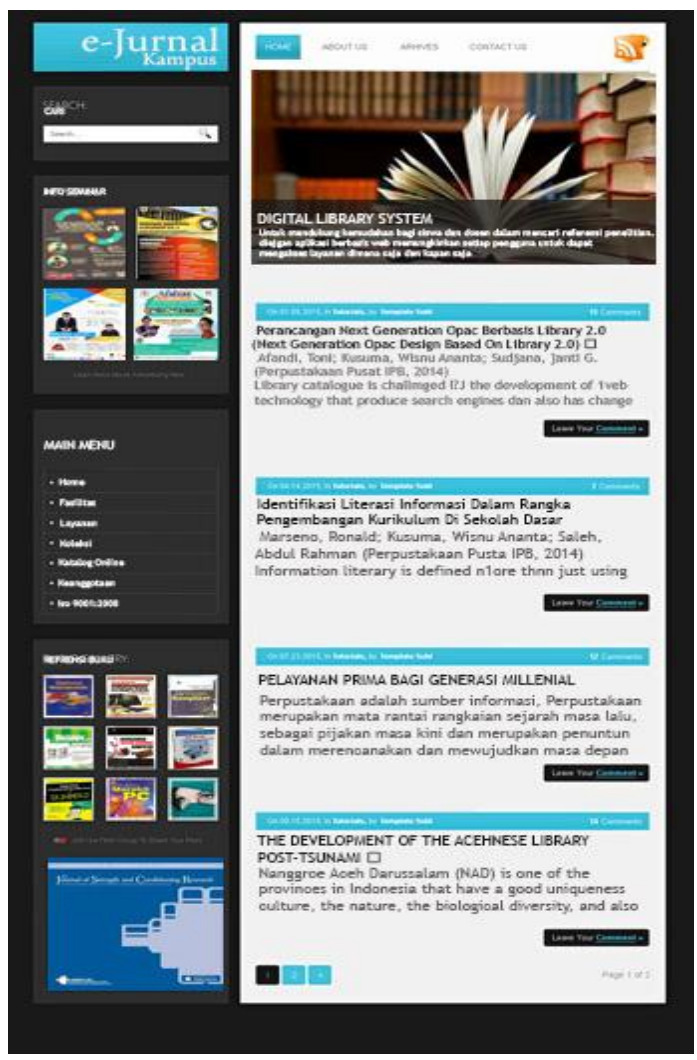

Gambar 5. Halaman Utama Pengunjung

\section{KESIMPULAN}

Berdasarkan penelitian yang sudah dilakukan dengan menggunakan data sekunder dan dari berbagai sumber ditemukan bahwa terdapat korelasi antara peningkatan jumlah penelitian dengan hasil penelitian yang di dokumentasikan dalam bentuk elektronik. Banyaknya jumlah pengunjung yang mengakses jurnal elektronik baik melalui computer atau mobile devices meningkat sehubungan dengan jumlah penelitian yang dihasilkan pada waktu yang berikutnya. Dan dengan perubahan media konvensional menjadi elektronik telah menghasilkan manfaat yang nyata. Dengan dimikian dapat diambil kesimpulan sebagai berikut:

1. Pencarian informasi yang diukur dengan jumlah pengunjung tiap jurnal dan halaman berbanding lurus dengan banyaknya jurnal yang dipublish

2. Para pelaku peneliti yang produktif dapat mengurangi waktu yang dihabiskan untuk menemukan sumber referensi dengan e-jurnal dibandingkan dengan media lainnya dan dapat lebih fokus dengan objek penelitiannya.

3. Sebagian besar peneliti sudah merasakan manfaat e-jurnal.

Dalam pencarian artikel jurnal, internet telah menjadi sarana yang efektif. Langganan jurnal secara elektronik di beberapa institusi resmi meningkat tajam untuk dijadikan sebagai sumber rujukan dan format yang paling disukai oleh pengguna sebagai bahan penelitian adalah format pdf 


\section{DAFTAR PUSTAKA}

[1].Jaringan Internasional untuk Ketersediaan Publikasi Ilmiah (INASP) untuk mengembangkan portal penelitian ilmiah di Afrika.

[2]. Nepal, (NepJOL) dimulai pada bulan Juni 2006 dan resmi diluncurkan pada bulan September 2007.

[3].ITB Journal of Science terbit dua kali setahun pada bulan Maret dan September. Naskah ditulis dalam bahasa Inggris. ISSN:1978-3043. di akses pada tanggal 16 may 2010.

[4].ITB Journal of Engineering Science terbit dua kali setahun pada bulan Mei dan November. Naskah ditulis dalam bahasa Inggris. ISSN: 1978-3051. di akses pada tanggal 16 may 2010

[5].ITB Journal of Information and Communication Technology terbit dua kali setahun pada bulan Mei dan November. Naskah ditulis dalam bahasa Inggris. ISSN: 1978-3086. di akses pada tanggal 16 may 2010

[6].ITB Journal of Visual Art and Design terbit tiga kali setahun pada bulan Maret, Agustus dan Desember. Naskah ditulis dalam bahasa Indonesia. ISSN: 1978-3078. di akses pada tanggal 16 may 2010.

[7].Institut Teknologi Bandung, pada http://www.lppm.itb.ac.id. di akses pada tanggal 16 may 2010.

[8].ITB Journal of Science dan ITB Journal of Engineering Science terakreditasi DIKTI dan diindex oleh Scopus. di akses pada tanggal 17 may 2010.

[9]. Mambrasar, yusuf. 2008. Membuat Aplikasi Web Server dengan Winsock. Yokyakarta: Andi.

[10]. Sidiq. Betha dan Husni Iskandar Pohan. 2010. Pemrograman WEB dengan HTML. Bandung: Informatika.

[11]. Suprianto. Dodit. 2008. Buku Pintar Pemrograman PHP. Bandung: Oase Media.

[12]. Raharja. Untung. Ir. 2009. Jurnal CCIT. Tangerang.

[13]. Prasetio. Adhi. 2014. Buku Sakti Webmaster (PHP \& MySQL, HTML \& CSS, HTML5 \& CSS3, JavaScript). Jakarta. Mediakita 